\title{
Apontamentos sobre a educação no Brasil Colonial (1549-1759)
}

\author{
Points to ponder about education in the Colonial period in Brazil (1549-1759)
}

Notes sur l'éducation au Brésil Colonial (1549-1759)

Notas sobre la educación en el Brasil Colonial (1549-1759)

\author{
Gleidson Silva ${ }^{1}$ \\ Simone Silveira Amorim ${ }^{1}$
}

Recebido em 13/01/2017; revisado e aprovado em 15/04/2017; aceito em 17/05/2017

DOI: http://dx.doi.org/10.20435/inter.v18i4.1469

\begin{abstract}
Resumo: O presente trabalho tem por objetivo apresentar aspectos da educação relacionados com a instrução dos gentios e a educação dos órfãos de posse no Brasil Colonial (1549-1759). A metodologia aqui utilizada configura-se como histórica e bibliográfica, com abordagem qualitativa. Foram utilizadas na pesquisa produções de Casimiro, Chambouleyron, Santos e Saviani.
\end{abstract}

Palavras-chave: história da educação; Brasil Colonial; primeiras letras.

Abstract: The present work aims to present aspects of education related to the instruction of the Gentiles and the education of the orphans of possession in the Colonial Brazil (1549-1759). The methodology used here is historical and bibliographical, with a qualitative approach. Productions of Casimiro, Chambouleyron, Santos and Saviani were used in the research.

Key words: history of education; Colonial Brazil; first letters.

Résumé: Cette étude vise à présenter les aspects de l'éducation liées à l'instruction des Gentils et l'éducation des orphelins en possession du Brésil colonial (1549 à 1759). La méthodologie utilisée ici est configuré comme historique et la littérature avec une approche qualitative. Ont été utilisés dans les productions de recherche de Casimiro, Chambouleyron, Santos et Saviani.

Mots-clés: histoire de l'éducation ; Brésil Colonial; premieres lettres.

Resumen: Este estudio tiene como objetivo presentar los aspectos de la educación relacionados con la instrucción de los gentiles y la educación de los huérfanos en posesión del Brasil colonial (1549-1759). La metodología utilizada aquí se configura como histórica y la literatura con un enfoque cualitativo. Se utilizaron en las producciones de investigación de Casimiro, Chambouleyron, Santos y Saviani.

Palabras clave: historia de la educación; Brasil Colonial; las primeras letras.

\section{INTRODUÇÃO}

O presente trabalho tem por objetivo apresentar aspectos da educação relacionados com a instrução dos gentios e a educação dos órfãos de posse no Brasil Colonial (1549-1759). Para tanto, serão pontuados aspectos que perpassam as etapas da educação no Brasil Colonial segundo a categorização de Saviani (2011). Ter-se-á como enfoque a educação na colônia durante os séculos de permanência dos jesuítas no Brasil, analisando-se o arcabouço norteador da ação pedagógica dos jesuítas que teve como propósito ensinar os gentios ${ }^{2}$, bem como educar e instruir os órfãos de posses após as reformas promovidas pelo Marquês de Pombal.

Ao tratar de um longo período como o Brasil Colonial, é preciso pensar a categoria "século" e sua definição segundo a sua função na narrativa histórica, pois o século histórico e o século cronológico possuem similitudes e que se sobrepõem na composição de narrativas históricas

\footnotetext{
${ }^{1}$ Universidade Tiradentes (UNIT), Aracaju, Sergipe, Brasil.

${ }^{2}$ No Brasil esse termo geralmente se refere aos indígenas que mantinham relações amistosas com os religiosos. Anterior à proibição da escravidão indígena (1570), exceto por meio da guerra justa, os portugueses chamavam os indígenas de "negros da terra", em referência aos cativos trazidos da África (SAVIANI, 2011).
} 
(SAVIANI et al., 2006). Um século histórico pode ultrapassar ou limitar-se à duração de um século cronológico. Pode-se dizer então que um "breve século" ${ }^{3}$ refere-se aos acontecimentos que demarcam temporalmente dentro da periodicidade de um século cronológico sem compreender a totalidade de cem anos. Logo, um "longo século" se refere a acontecimentos que transpassam a limitação de um século cronológico e perpassam por mais de um século.

Nesse sentido, segundo Saviani (2011), pode-se dividir o período colonial brasileiro em três etapas para melhor compreender aspectos da educação brasileira. A primeira etapa corresponde ao período de 1549 a 1599, a segunda etapa corresponde ao período de 1599 a 1759, e a terceira e última etapa corresponde ao período de 1759 até o ano de 1808.

A primeira etapa é chamada de "período heroico", compreendendo o movimento de chegada dos primeiros jesuítas ao Brasil. Esses religiosos tinham a atribuição de converter os gentios, tendo como instrumento fundamental a catequese. O marco final desse período se dá pela criação do Ratio Studiorum que ajustou a prática dos inacianos na educação dos povos da Colônia.

Já o segundo período é marcado pela consolidação dos jesuítas, enquanto Ordem missionária e sua hegemonia no campo da educação, não somente dos gentios, mas também dos filhos dos colonos e da elite colonial. A prática pedagógica nesse contexto esteve alicerçada no Ratio Studiorum que se configurou como instrumento regulador do ensino ministrado pelos inacianos.

O terceiro e último período é marcado pela expulsão dos jesuítas do Brasil e pelas reformas implementadas pelo Marquês de Pombal. Sob forte influência iluminista, as reformas pombalinas buscaram difundir os rudimentos elementares da ciência e das luzes tanto na metrópole como no além-mar. O marco final dessa etapa é sinalizado pela fuga da família real portuguesa para o Brasil, junto com a sua corte.

Entretanto o recorte temporal da presente pesquisa tem relação com a chegada dos primeiros jesuítas com a armada de Tomé de Souza, primeiro Governador Geral, em 1549, perpassando pela expulsão dos jesuítas de Portugal e de suas possessões territoriais além-mar, até as medidas tomadas pelo Marquês de Pombal, em 1759.

A metodologia aqui utilizada se configura como histórica e bibliográfica, com abordagem qualitativa. Histórica, por estabelecer apontamentos das práticas e dos agentes que se encontram no tempo pretérito. Bibliográfica, pelo fato de esse texto ser baseado nos trabalhos de Casimiro (2007), Chambouleyron (2004), Santos (2011) e Saviani (2011), utilizados na tessitura do texto.

A partir dessas produções, buscou-se apontar traços da atuação pedagógica dos jesuítas no ensino dos gentios, filhos dos colonos, bem como a educação e a instrução dos órfãos de posses, bem como evidências que indicassem a instrução para os estratos da sociedade colonial.

\section{CONSIDERAÇÕES SOBRE A EDUCAÇÃO NO PROCESSO DE COLONIZAÇÃO DO BRASIL}

O processo de colonização do território brasileiro empreendido pela Coroa portuguesa buscou a manutenção do monopólio das possessões no além-mar. A presença constante de franceses na costa brasileira, os conflitos com habitantes nativos (íncolas ${ }^{4}$ ) e o movimento de contrarreforma na Europa reforçaram as medidas de proteção da colônia no novo mundo.

\footnotetext{
${ }^{3}$ Para mais informações sobre a categoria século recomendo a leitura do livro de Eric J. Hobsbawn (1995): A era dos extremos: o breve século XX (1914-1991).

${ }^{4}$ Segundo Saviani (2011, p. 26, apud BOSI, 1992, p. 11), ao discutir o conceito de colonização, busca-se na etimologia da palavra a sua origem no verbo latino Colo. Dessa forma, define que "colo significa, na língua de Roma, eu moro, eu ocupo a terra, e, por extensão, eu trabalho, eu cultivo o campo. Um herdeiro antigo de colo é incola, o habitante; outro é inquilinus, aquele que reside na terra alheia".
} 
A relação entre o Coroa portuguesa e a Igreja Católica nesse contexto contribuiu para a presença de ordens ${ }^{5}$ religiosas no Brasil. Dentre as diversas Ordens que estavam atuando na conversão dos nativos para a fé católica, destaca-se aqui a atuação dos Jesuítas.

Segundo Saviani (2006), o "brevíssimo século XVI" compreende ao processo pedagógico conhecido como "pedagogia brasílica", que teve início com a chegada dos primeiros jesuítas ao Brasil, em 1549, e se estendeu até a instituição do Ratio studiorum, em 1599.

A Companhia de Jesus, criada pelo padre Inácio de Loyola, em 1534, e reconhecida em 1540 através de bula papal ${ }^{6}$, possuía característica militante, missionária e instrutiva. Enquanto a atuação da Ordem na Europa estava voltada para o combate à expansão do protestantismo, no Brasil, voltou-se para a educação dos povos silvícolas por intermédio da catequese e no estabelecimento de aldeamentos para ocupação do território.

Na Europa, a função religiosa da Companhia de Jesus foi, sobretudo, o combate aos hereges. A função educativa manteve-se voltada para a formação dos seus próprios quadros e para a educação dos filhos da elite. Nos territórios colonizados, a ação evangelizadora dos jesuítas tomou outro rumo, por causa dos interesses da política econômica sobre as colônias e da existência da escravidão. (CASIMIRO, 2007, p. 90).

A atuação combativa, na Europa, aos hereges e ao movimento protestante tornou-se a principal função da ordem no campo religioso, enquanto que a sua função educativa esteve voltada apenas para formação de novos inacianos e dos filhos das elites, assim como nas colônias a atuação evangelizadora dos jesuítas possuía uma dupla função: a conversão e a defesa dos indígenas. Embora combatessem a escravidão dos índios, por outro lado, apoiavam a escravidão africana.

Apesar de ser uma Ordem com poucos anos de existência, a Companhia de Jesus, gozava de vários privilégios junto à Corte portuguesa naquele período. Seu caráter militar e pedagógico proporcionou a presença dos jesuítas nas possessões coloniais portuguesas no Oriente e no Ocidente.

A atuação pedagógica dos jesuítas influenciou o modo de educar os indivíduos na colônia segundo as suas posições sociais. Isso levou a níveis distintos de instrução: para os índios, os rudimentos da língua e os ofícios; para os brancos libertos, os rudimentos da escrita, da leitura e os ofícios; para as classes abastadas, os ensinos superiores que garantiriam a manutenção da estrutura de poder; já para os escravos africanos e alforriados, os ofícios.

Nesse contexto, a educação pode ser entendida como o processo no qual a humanidade, a partir da tradição acumulada, elabora a si mesma em seus mais diversos aspectos. Assim, é possível distinguir três pontos fundamentais: inculturação ${ }^{7}$ da tradição e dos costumes; a instrução intelectual em sua dimensão formal-instrumental e concreta ${ }^{8}$; aprendizagem de ofícios (MANACORDA, 1989).

O processo de aculturação ${ }^{9}$ dos íncolas fez parte do plano de dominação com a transmissão de hábitos, costumes e normas ditas civilizadas para os índios. Para tanto, era preciso fazer

\footnotetext{
${ }^{5}$ Segundo Saviani (2011), as ordens que vieram ao Brasil durante o processo de colonização foram as dos Franciscanos, Beneditinos, Carmelitas, Oratorianos e Capuchinhos.

${ }^{6}$ Regimini militantis, 27 de setembro de 1540 publicada pelo Papa Paulo III.

${ }^{7}$ Refere-se à cultura cristã e as adaptações culturais realizadas pelas diferentes culturas.

${ }^{8}$ Segundo Manacorda (1989, p. 6), seria o conteúdo do conhecimento.

${ }^{9}$ Entende-se que o processo de colonização do Brasil não é um formado por aculturação apenas dos índios, mas sim de toda uma concepção de vida nos trópicos para os europeus que aqui chegavam. Assim entende-se também que o processo de aculturação foi uma via de mão dupla. Contudo vale salientar que a cultura dominante prevaleceu em diversos aspectos.
} 
com que os indígenas aprendessem os rudimentos da civilidade e, para isso, a catequese teve papel fundamental naquele contexto, sendo primordial para tal empreendimento colonizador.

O processo de colonização abarca, de forma articulada mas não homogênea ou harmônica, antes dialeticamente, esses três movimentos representados pela colonização propriamente dita, ou seja, a posse e exploração da terra subjugando os seus habitantes (os íncolas); a educação enquanto aculturação, isto é, a inculcação nos colonizadores das práticas, técnicas, símbolos e valores próprios dos colonizadores; e a catequese entendida como a difusão e conversão dos colonizados à religião dos colonizadores. (SAVIANI, 2011, p. 29).

Nesse sentido, vale salientar que o processo de colonização não foi homogêneo em toda a extensão do território, muito menos foi harmônica a ocupação, tendo em vista que os confrontos com os povos indígenas aconteciam por causa do cativeiro para o trabalho escravo e a desapropriação de lugares considerados pontos estratégicos para a Coroa portuguesa.

A atuação dos jesuítas na educação no Brasil foi marcada pelo plano de instrução ${ }^{10}$ criado pelo Padre Manoel de Nóbrega, chefe dos jesuítas no Brasil. Sua estratégia para organizar o ensino e ter maior efetividade teve como foco agir sobre os filhos dos indígenas, fazendo uso dos órfãos enviados de Lisboa à sua possessão no novo mundo. Essas crianças serviram de ponte entre os jesuítas e os meninos índios.

De acordo com Saviani (2011), o pensamento pedagógico de Manoel da Nóbrega possuiu três aspectos capilares: filósofo da educação, por entender, em sua generalidade, as ideias pedagógicas; teórico da educação, por organizar os meios para a realização dos trabalhos educativos; e prático na pedagogia, por ter realizações significativas no processo de ensino-aprendizagem.

Como ideias pedagógicas se encarnavam, assim, na realidade da colônia, assumindo, em Nóbrega, dominantemente a forma da organização dos meios considerados adequados para se colimarem os fins preconizados: a sujeição dos gentios, sua conversão à religião católica e sua conformação disciplinar, moral e intelectual à nova situação. [...] de acordo com as 'pedagogias e ética missionária', a sujeição dos índios precede à conversão, sendo condição necessária de sua eficácia. (SAVIANI, 2011, p. 44).

Essa pedagogia, atribuída a Manoel de Nóbrega, que prevê a conversão do indígena e a doutrinação, está relacionada com a ideia de "civilizar pela palavra". Foi aperfeiçoada pelo padre José de Anchieta, ao criar a gramática da língua geral, que serviu para o trabalho pedagógico na colônia.

Uma das técnicas usadas pelo Padre Anchieta foi o teatro, explorando temas religiosos e apelando para a dualidade antológica com o uso de alegorias. Os teatros de Auto ${ }^{11}$ serviram como instrumento pedagógico por mostrar, a partir de encenações, a disputa sempre latente entre o bem contra o mal. A culminância entre o plano de estudos do Nóbrega e as técnicas pedagógicas aplicadas por Anchieta deram forma ao que ficou conhecido como "pedagogia brasílica". Essa pedagogia esteve pautada no instrumento de catequese, com o uso de alegorias, e por meio do teatro de auto. Foi uma pedagogia aplicada às necessidades e pelos meios disponíveis aos jesuítas nas terras conquistadas pelos portugueses na América (SAVIANI, 2011).

\footnotetext{
10 “[...] O plano iniciava-se com o aprendizado do português (para os indígenas); prosseguia com a doutrina cristã, a escola de ler e escrever e, opcionalmente, canto orfeônico e música instrumental; e culminava em um lado, com a gramática latina para aqueles que se destinavam à realização de estudos superiores na Europa (Universidade de Coimbra)" (SAVIANI, 2011, p. 43).

${ }^{11}$ Estilo teatral que surge como subgênero da literatura dramática no período medieval.
} 
Contudo a coletânea de experiências pedagógicas aplicadas ao colégio jesuíta de Roma deu subsídios para a criação do Ratio Estudiorum ${ }^{12}$ (Plano de Estudos) o que ajustou as práticas que eram pautadas no Plano de instrução do Padre Manoel da Nóbrega. O objetivo do Ratio Estudiorum era instruir rapidamente todos os jesuítas ${ }^{13}$ sobre a extensão, a natureza e as obrigações no desempenho de suas atividades pedagógicas.

Esse documento de ajustamento de condutas surge em meio à necessidade de unificar os procedimentos pedagógicos dos jesuítas diante do alto número de colégios confiados à Companhia de Jesus. Composto por 467 regras, o Ratio Estudiorum foi sistematicamente abrangente, pois cobria todos os campos da atividade pedagógica dos jesuítas.

As ideias pedagógicas expressas no Ratio correspondem ao que passou a ser conhecido na modernidade como pedagogia tradicional. Essa concepção pedagógica caracteriza-se por uma visão essencialista do homem, isto é, o homem é concebido como constituído por uma essência universal e imutável. A educação cumpre moldar a existência particular e real de cada educando à essência universal e ideal que o define enquanto ser humano. Para a vertente religiosa, tendo sido o homem feito por Deus à sua imagem e semelhança, a essência humana é considerada, pois, criação divina. Em consequência, o homem deve empenhar-se em atingir a perfeição humana na vida natural para fazer por merecer a dádiva da vida sobrenatural. (SAVIANI, 2011, p. 58).

Essas ideias, essencialmente, estão baseadas no tomismo, sob a influência da filosofia aristotélica e da tradição cristã, com referência ao pensamento do filósofo e teólogo medieval São Tomaz de Aquino, de onde deriva a designação da corrente.

Com a instituição do Ratio Studiorum os colégios jesuítas passaram a ter o mesmo estatuto para toda a Ordem nos mais diversos lugares. No Brasil, esses colégios converteram-se em instrumentos de formação da elite colonial passando, dessa forma, a aplicar as dimensões universais e elitistas previstas no plano de estudos.

\section{A INSTRUÇÃO DOS GENTIOS E CRIANÇAS: A AÇÃO DOS INACIANOS NA EDUCAÇÃO COLONIAL}

A conversão e instrução dos gentios na colônia portuguesa no além-mar fez parte da ação autorizada pelo Estado português, que pretendia manter o monopólio das possessões territoriais e converter os indígenas à fé católica. Esta última ficou sob a responsabilidade da Companhia de Jesus, que surgiu como Ordem missionária de caráter militar e religiosa que atuou no combate aos protestantes, no contexto da contrarreforma.

Embora a Companhia de Jesus possuísse uma postura mais combativa nos países Ibéricos, no Brasil, a sua atuação se debruçou na instrução dos gentios e das crianças. Para tanto, foi necessário construir um arcabouço norteador da ação educativa e a criação de espaços para a catequese e a instrução dos gentios e das crianças.

Os primeiros irmãos da Companhia de Jesus vieram ao Brasil para evangelizar e catequisar os povos indígenas, função destoante da realizada pela Ordem na Europa, no movimento de

\footnotetext{
${ }^{12}$ Segundo Saviani (2011), esse método suplantou o modus parisiense e o modus itálico no colégio jesuítico de Roma.

${ }^{13}$ Vale ressaltar que, dentro da Ordem, havia membros que tinham a função específica de ensinar. Tendo em vista que as funções da Ordem na Europa iam muito além dos fazeres pedagógicos.
} 
contrarreforma, sob a determinação do governo português. Os inacianos ${ }^{14}$ chegaram ao Brasil sob a proteção da armada do primeiro Governador Geral, Tomé de Souza, em 29 de março 1549. Os Jesuítas, liderados pelo padre Manoel de Nóbrega, depararam-se com uma terra que deveria ser colonizada e homens e mulheres a serem convertidos à fé católica.

Foi sob a égide do Estado português e com a permissão do Papa que iniciativas dos Jesuítas se voltaram para a conversão dos gentios e a instrução das crianças na colônia. A Companhia de Jesus tinha a função missionária como objetivo primeiro, contudo ela se revelou uma "Ordem docente" ao se debruçar sobre a formação da mocidade, além da formação dos seus próprios membros (CHAMBOULEYRON, 2004).

Segundo Casimiro (2007), o ensino no período colonial pode ser dividido em quatro enfoques diferentes que perpassam pela instalação das ordens religiosas ainda no século XVI, fato que demarca a proposta dos Jesuítas em ensinar as primeiras letras ${ }^{15}$ e o evangelho aos pequenos índios; pela construção dos primeiros colégios e a consolidação do modelo educativo dos jesuítas no século XVII; pela instalação das missões como meio de garantir a propagação da fé e a manutenção da posse da terra conquistada; por fim, pelo apogeu da organização da Companhia de Jesus e a expulsão dos jesuítas de Portuga ${ }^{16}$ e de suas possessões no além-mar no início da segunda metade do século XVIII, culminando na implantação de ideias ilustradas e reformas no modelo educacional através da ascensão do Marquês de Pombal, em 1759.

De acordo com Saviani (2006), o período que se estende de 1599 a 1759 é considerado como "longo século XVII" correspondendo ao período de organização dos estudos na Colônia e vigência do Ratio Estudiorum até a expulsão dos jesuítas de Portugal e no além-mar.

Assim, por mais de dois séculos, a hegemonia da instrução no Brasil Colônia esteve sob o poder dos Jesuítas que tinham como base três documentos norteadores da sua prática pedagógica: Exercícios Espirituais; as Constituições da Companhia de Jesus escrita pelo padre Inácio de Loyola; e a Ratio Atque institutio Studiorum societatis lesu ${ }^{17}$, comumente chamada de Ratio Studiorum. A instrução dos gentios e das crianças esteve pautada nos ensinamentos veiculados através desses documentos, em especial Exercícios Espirituais e o Ratio Studiorum, que estabeleceram a base do modo educativo dos inacianos.

De acordo com Casimiro (2007), os Exercícios Espirituais serviram de instrumento modelador da prática pedagógica dos jesuítas, atuando como manual de orientação espiritual. Esse documento foi escrito por Inácio de Loyola com o propósito de auxiliar os companheiros da ordem a organizar e fortificar a sua atividade espiritual. Assim como o corpo necessita de exercícios, Inácio de Loyola entendia que era preciso também exercitar o espírito.

Outro documento também escrito por Inácio de Loyola foram as Constituições da Companhia de Jesus, finalizadas em 1551. Esse documento, mais especificamente na sua quarta parte $^{18}$, trata da educação no âmbito escolar e das instituições educativas. Tinha por propósito

\footnotetext{
${ }^{14}$ Termo usado como referência aos membros da Ordem Jesuíta, criada pelo Padre Inácio de Loyola.

${ }^{15}$ A instrução das primeiras letras esteve submetida à hegemonia do ensino jesuítico, contudo "Além da Companhia de Jesus, outras ordens religiosas também foram responsáveis por segmentos da educação colonial, como as ordens dos carmelitas, mercedários e franciscanos" (CASIMIRO, 2007, p. 88).

${ }^{16}$ A expulsão dos jesuítas tenha relação com o intrigante e nebuloso processo dos Távoras, episódio no qual foram julgados e condenados os suspeitos de tentar executar o Rei D. José I em 1758, já que o confessor da Marquesa Leonor de Távora era um jesuíta (Gabriel Malagrida).

${ }^{17}$ Plano e Organização de Estudos da Companhia de Jesus.

${ }^{18}$ Intitulada "Como instruir nas letras e em outros meios de ajudar o próximo e os que permanecerem na Companhia"
} 
manter a uniformidade da Ordem que estava em expansão, o que exigia o estabelecimento de características básicas que deveriam fazer parte dos colégios jesuítas nos mais diversos ambientes culturais (SAVIANI, 2011).

Por fim, o documento criado para a organização da prática pedagógica dos jesuítas foi o Ratio Studiorum em 1599, que tinha a prerrogativa de tratar sobre as razões da educação da Companhia de Jesus e suas influências sobre a educação escolar e a pedagogia como um todo. Embora o seu conteúdo não tenha uma abordagem pedagógica (sistematicamente educativa), ele expressa categoricamente as atividades que devem ser realizadas pelos membros da companhia, as suas funções dentro da hierarquia da Ordem, as metodologias de abordagem e os modos de avaliação aplicados nos Colégios Jesuítas.

A maneira como foram elaboradas as Constituições e a Ratio garantiram o caráter unitário do modo de vida jesuítico e permitiram uma flexibilidade e autonomia que possibilitaram a propagação do apostolado da Companhia por todo o orbe cristão. Esses três documentos foram as diretrizes que garantiram a uniformidade da prática pedagógica dos jesuítas em toda a sua caminhada missionária e doutrinária, com adaptações necessárias, caso se tratasse do Império Português, do combate aos hereges, da evangelização dos europeus, da catequese dos negros da terra do Brasil (índios) ou dos africanos escravizados. (CASIMIRO, 2007, p. 93).

Graças à flexibilidade e autonomia garantidas pelas Constituições da Companhia de Jesus pelo Ratio Studiorum e pelos Exercícios Espirituais, em certa parte, possibilitaram a inserção da Ordem nas diversas esferas do mundo cristão ibérico e ocidental. A adequação às diferentes realidades em que atuaram os inacianos tornou-se necessária para o sucesso da missão catequética e evangelizadora no Brasil, tendo em mente as diferentes frentes de atuação da Ordem na Europa.

Sob esse arcabouço norteador da ação educativa, os jesuítas buscaram nas crianças indígenas o caminho para se chegar aos adultos, tendo em vista que "[...] a evangelização das crianças tornara-se uma forma de viabilizar uma difícil conversão, já que, [...] nos meninos se poderia esperar muitos frutos, uma vez que pouco contradiziam a lei cristã." (CHAMBOULEYRON, 2004, p. 58). Uma das muitas estratégias para atrair os filhos dos gentios foi a "importação" de órfãos de Portugal, medida que pretendia dar mais efetividade na catequese dos meninos indígenas.

Em razão da sua vivência apostólica e da própria descoberta da infância, os padres entenderam que era sobre as crianças, essa 'cera branda', que deveriam imprimir-se caracteres da fé e virtude cristãs. Para isso elaboraram estratégias e projetos, que se transformavam à medida que se consolidava a própria conquista portuguesa na América, e que seguiam os ventos traziam e enviavam suas cartas ao Velho Mundo. (CHAMBOULEYRON, 2004, p. 79).

As metodologias utilizadas para a instrução das primeiras letras às crianças indígenas, bem como à doutrinação católica, estiveram permeadas por práticas que iam desde representações teatrais, cânticos e música instrumental, catecismo dialogados e a memorização pela repetição. O propósito dos Jesuítas em educar as crianças estava em formar uma cristandade no além- mar que se mantivesse fiel à Santa Sé e na mudança de costumes e práticas comuns nas tribos indígenas como a poligamia, nudez e a antropofagia.

Mas era principalmente na vida religiosa que os meninos eram preparados para formar a 'nova cristandade' sonhada pelos religiosos da Companhia de Jesus. A educação das crianças

(CASIMIRO, 2007, p. 92).

INTERAÇÕES, Campo Grande, MS, v. 18, n. 4, p. 185-196, out./dez. 2017. 
implicava, assim, uma transformação radical da vida dos jovens índios. (CHAMBOULEYRON, 2004, p. 61).

Vale também ressaltar que a catequese, enquanto prática de doutrinação concatenada com o ensino dos conhecimentos elementares para a formação moral e cristã das crianças, implicou em transformações significativas na vida dos jovens índios.

Com a consolidação do método de ensino jesuítico no século XVII, os colégios se tornaram locais de educação formal ${ }^{19}$. Embora inicialmente tenham sido construídos para formar novos inacianos na Europa, passaram a instruir também os filhos da elite colonial no Brasil. Contudo o grau de ensino era diferenciado de acordo como o estrato social dos indivíduos. Casimiro (2007, p. 87), demostra que:

[...] os brancos, portugueses, filhos da elite, eram alvo de uma educação formal, longa e diversificada, preparatória para o poder e/ ou para a vida eclesiástica. [...] Outros portugueses, pertencentes aos segmentos restritos das classes populares, tinham acesso apenas aos rudimentos escolares: isto é, ler, escrever e contar; [...] para os índios e mestiços, a educação era ministrada nas missões, nos engenhos e nas igrejas. A estes ensinava-se, precariamente, o catecismo preparatório para o batismo, para a vida cristã, além de ofícios e tarefas servis que, naquele tempo, por serem consideradas desonrosas, não podiam ser executadas pelos brancos; [...] os colonizadores desenvolveram, também, pedagogias para tratar da educação/ evangelização dos escravos.

Pode-se observar que a educação para funções elevadas na estrutura do estado, ou do mundo eclesiástico, era resguardada para a elite dominante. Já os demais estamentos da sociedade recebiam a instrução dos conhecimentos necessários para o trabalho, para a civilidade e submissão aos ditames da fé católica.

No Brasil, o foco da educação jesuítica mudou com o passo do tempo, contudo a sua ação missionária não parou, pois continuaram a fazes missões ${ }^{20}$ e a catequisar povos indígenas. Os colégios jesuítas estiveram, então, direcionados à educação intelectual concreta da elite colonial, preparando-os para o ingresso na faculdade de Coimbra.

A população branca e menos abastada recebia uma educação formal-instrumental (ler, escrever e contar) e a aprendizagem de ofícios de acordo com suas atividades dentro da sociedade colonial. Entretanto, segundo Casimiro (2007), os "desclassificados" ${ }^{21}$ socialmente recebiam também educação para os ofícios de acordo com a sua posição dentro da estrutura social colonial.

Já a educação feminina era eminente confessional. Algumas ordens religiosas acolhiam jovens em situação de risco, ou seja, que não possuíam bens nem familiares, bem como havia jovens que eram mandadas por seus pais ou responsáveis para receber uma educação esmerada nos conventos. Essas mulheres recebiam uma educação formal-instrumental, educação para a casa e a formação moral e religiosa.

\footnotetext{
${ }^{19}$ Embora nesse contexto as "escolas" ou a universidade, ou seja, instituições específicas da formação educacional formal, ainda não existissem na colônia, é possível reconhecer que os colégios jesuíticos exerceram o papel de ensinar a ler, escrever e a doutrina cristã, bem como conhecimentos elementares para o ingresso ao ensino superior na metrópole.

${ }^{20}$ Missões, ou também conhecidas como reduções (sentido de redirecionar e não diminuir), eram nomes dados ao aldeamento de indígenas organizado por membros da Companhia de Jesus no Brasil, como na América espanhola (SAVIANI, 2011).

21 "Faziam parte de uma realidade composta de filhos de escravos domésticos, órfãos, crianças abandonadas, filhos ilegítimos (inclusive filhos de padres), mestiços, negros alforriados etc., para os quais havia formas de educação distantes do padrão vigente" (CASIMIRO, 2007, p. 87).
} 
Com a expulsão dos jesuítas do Brasil, em 1759, foram implantadas as reformas do Marquês de Pombal, pelo Alvará Régio de 28 de junho de 1759, que mudaram a estrutura de educação em Portugal e em suas possessões além-mar. Com a expulsão dos jesuítas, foram criadas escolas de ensino secundário e primário, o que demandou a contratação de professores laicos e religiosos.

Com fortes influências das ideias iluministas, o Marquês de Pombal buscou reformar o currículo das escolas e da faculdade de Coimbra, alinhando Portugal às mudanças promovidas pelas luzes e pelo saber científico.

Entretanto, em sua essência, o ensino continuou com fortes traços da pedagogia jesuíta. No Brasil, por exemplo, muitos religiosos de outras ordens e os indivíduos letrados que concorreram às Aulas Régias tinham forte influência dos jesuítas em suas práticas educativas, o que pode ser entendido como legado de uma cultura pedagógica que permeou a forma de ensinar durante o período colonial (1500-1808) ate os anos iniciais do período imperial (1808-1889).

\section{A EDUCAÇÃO DOS ÓRFÃOS DE POSSES EM SERGIPE}

A educação das classes abastadas tinha o propósito de direcionar, no caso dos meninos, para o governo dos negócios da família podendo ocupar cargos de comando dentro da estrutura governamental, jurídica ou legislativa na Colônia. Já as meninas recebiam a educação para o governo da casa, aprendiam a cuidar dos filhos, do marido e da organização do espaço familiar.

Mas o fato de as mulheres, geralmente, não terem acesso à instrução escolarizada não constituiu regra. Isso não significa que algumas não aprendessem a ler e a escrever. Pode-se citar, por exemplo, o inventário de Manuel Caetano do Lago, falecido em 1796, o qual Dona Maria Francisca de Freitas, sua viúva, assinou de próprio punho. O Tenente Manuel deixou duas filhas órfãs menores de idade: Micaely, com 10 anos, e Maria Benta, com dois anos de idade (SANTOS, 2011).

O falecimento de um fidalgo, ou senhor de posses, gerava a necessidade de manutenção do poder patriarcal (pátrio poder) e do prestígio exercido pelo nome da família; nessa situação, buscava-se na justiça, por intermédio de instrumentos como inventário de bens, testamentos e cartas de tutoria, mecanismos legais para manutenção da família e dos seus dependentes.

Segundo as Ordenações Filipinas 22 (1870), em caso de falecimento do provedor da família, eram considerados herdeiros diretos ascendentes os pais do falecido e herdeiros descendentes, os filhos e a cônjuge em regime de comunhão de bens. Previa também a participação de juízes de órfãos e tabeliões na confecção dos inventários dos bens do falecido.

Sendo uma determinação jurídica, os inventários eram feitos para os que tivessem bens para deixar. Podiam ser abertos pela família ou, na falta desta, pelo Juiz dos Órfãos, quando havia filhos menores. Então, quando morria uma pessoa num determinado local, era comum o tabelião receber tal comunicado em sua própria casa. O inventariante procurava o Juiz dos Órfãos do lugar e fornecia as informações gerais do defunto, as quais eram dispostas na primeira página do documento. Este era denominado de autuação e nela constavam o nome do falecido, local de moradia e data de falecimento, seguido da lista dos herdeiros e as suas respectivas idades, situação conjugal dos mesmos e os nomes dos filhos mortos com sua idade à época. (SANTOS, 2011, p. 32-33).

\footnotetext{
${ }^{22}$ Extenso conjunto de regras e condutas que foram criadas durante o Reinado de Felipe I em 1595, durante o período conhecido como União Ibérica, mas que vigoraram, a partir de 1603, no Reinado de Felipe II, seu sucessor.
} 
O inventário era um documento solicitado por um inventariante ${ }^{23}$ com o propósito de avaliar os bens pessoais e posses do falecido a fim de repartir o montante, de forma igualitária, entre os herdeiros. Dessa forma, garantia-se recursos para a manutenção dos menores ${ }^{24}$ e da viúva. Como estratégia para manutenção da posição e dos privilégios dentro da estrutura da sociedade colonial, era preciso garantir a educação necessária dos menores órfãos de acordo com o seu sexo. Para tanto, era preciso que o responsável legal, poderia ser a própria mãe ou um tutor, investisse na educação da criança órfã.

Segundo Santos (2011), tinha-se a cobertura legal para garantir a educação do menor órfão, bem como a fiscalização se a educação dele estava sendo garantida e se estava em consonância com a legislação que previa distinção entre a educação de meninos e meninas. As mães tinham a obrigação de prover seus filhos com a primeira educação, compreendendo-se como a que se inicia nos joelhos da mãe que os ensina a andar, falar, comer, vestir, a se comportar e depois os encaminha para a instrução.

No caso dos meninos, estes eram instruídos a ler, escrever, contar e na doutrina cristã sendo direcionados para o governo dos negócios da família. Ingressando nos ensinos superiores chegando até a faculdade de Coimbra, para cursar direito ou medicina, a depender da posição e prestígio da família na sociedade colonial (SANTOS, 2011).

Já no caso das meninas, os processos educativos estiveram ligados à educação para o governo da casa, aprendia-se a doutrina cristã, os bons costumes, cozer e a fazer renda (SANTOS, 2011, p. 246). Em alguns casos $^{25}$, as famílias encaminhavam as jovens para viver enclausuradas em conventos ou internatos onde o ensinamento da doutrina cristã e dos afazeres domésticos eram aprendidos conjuntamente com a educação do corpo e o controle dos desejos mundanos.

[...] a ação educativa do convento consistia em preparar a mulher para a labuta da casa e dos filhos, uma vez que a ela seria confiada a educação dos filhos na primeira infância e ainda a responsabilidade pelo suporte moral da família, papéis fundamentais no plano de Deus e da sociedade. [...] os ensinamentos eram ministrados, considerando duas faixas etárias, distinguindo o nível de maturidade das alunas: a primeira envolvia crianças de 06 a 12 anos de idade, sendo esse momento propício à formação da razão, do caráter, da consciência e dos bons hábitos das alunas; já a segunda envolvia crianças a partir dos 12 anos de idade. Esta era considerada uma fase de transição, posto que a menina precisaria ser cuidada com muita simpatia, pois era o momento em que se aprendia a ordenar os impulsos e as vontades, abdicando, desse modo, aos desejos em favor dos princípios morais definidos pela igreja e pela sociedade. (SANTOS, 2011, p. 199).

A instrução das meninas no regime de clausura nos conventos e internatos religiosos tinha o intuito de preparar a jovem para a vida em família. Para tanto, era preciso aprender a cuidar da casa, dos filhos e apreender a moralidade, projetada sobre a figura da mulher, na sociedade colonial. A "educação da mulher restringia-se à aprendizagem de boas maneiras e prendas domésticas; elas deveriam aprender a ser boas mães e boas esposas. Mesmo as oriundas de famílias mais abastadas não tinham assegurado o acesso à instrução escolarizada" (FARIA, 1998, p. 35). Para isso a educação das meninas permeava, ainda na primeira infância, aspectos da formação

\footnotetext{
${ }^{23}$ Poderia ser a mulher do falecido, o filho mais velho ou até mesmo um juiz de órfão no caso do falecimento dos pais.

${ }^{24}$ Segundo as Ordenações Filipinas (1870), eram considerados menores perante a lei pessoas com menos de 25 anos.

${ }^{25}$ Segundo Santos (2011), o enclausuramento de jovens poderia ser por questões financeiras da família, por não ter um dote para que a jovem conseguisse um pretendente do mesmo estrato social, ou para manter a castidade das jovens até arranjar um marido. Entretanto, a autora demostra que algumas enclausuradas acabavam tornando-se freiras.
} 
do caráter, fortalecimento da consciência e imposições de hábitos comportamentais. Já a partir dos 12 anos havia uma preocupação maior com aspectos morais e a formação dos sentidos, período em que se buscava reprimir as vontades e controlar os desejos, segundo o padrão aceito pela sociedade da época.

Nesse sentido, a educação feminina ia muito além do aprender a cuidar da casa, dos filhos e do marido. A mulher aprendia a ser submissa, a ter que controlar seus desejos e vontades, manter o recato e uma postura moral imposta pela sociedade. Assim, a educação na clausura dos conventos e internatos foi sinônimo de uma educação ilibada. Possibilitava a doutrinação da mulher para ser o pilar da família, ensinando os cuidados da casa e a ser uma senhora respeitada segundo o padrão de comportamento com princípios religiosos aflorados na sua mansidão e conduta submissa. Os muros dos conventos e internatos mantinham a segurança e a lisura da castidade dessas jovens que esperavam pelo casamento.

A dimensão da educação para os órfãos tinha forte relação com o local ocupado pela família à qual pertencia. Famílias com poucas posses eram obrigadas a dar uma educação condizente com o seu nível, o que limitava o tipo de ensino que o órfão, independente do sexo, receberia.

\section{CONSIDERAÇÕES FINAIS}

A ação dos jesuítas na instrução dos gentios e crianças no período colonial teve enfoques distintos que perpassaram desde a doutrinação cristã dos gentios, o ensino das primeiras letras para as crianças, ensino de ofícios para os trabalhadores pobres livres e até o ensino das humanidades latinas para os filhos da elite colonial. Forneceu à sociedade colonial brasileira indivíduos que possuíssem os conhecimentos necessários para a civilidade, manutenção do poder estabelecido e a obediência à fé católica.

Assim, compreende-se que a ação "docente" dos jesuítas, desenvolvida na Colônia, configurou-se como determinante na difusão dos conhecimentos necessários para cada estrato da sociedade colonial. Contudo vale aqui ressaltar que a Companhia de Jesus não era a única Ordem religiosa a ofertar instrução durante o período colonial, mas deve-se frisar também que até a expulsão da Ordem, em 1759, a hegemonia do ensino dos gentios e a formação da elite colonial estiveram sob o domínio dos inacianos.

Pode-se concluir que a ação pedagógica desenvolvida pela Ordem dos Jesuítas no Brasil permeou os diversos níveis de instrução na Colônia portuguesa no além-mar. Na ausência de instituições de instrução formal no Brasil, os colégios jesuíticos tornaram-se polos de instrução formal (ensino das primeiras letras e o ensino das humanidades latinas), proporcionando a instrução considerada necessária para cada estamento da sociedade colonial.

A educação dos órfãos de posse era uma necessidade para a manutenção de toda uma estrutura de poder e posições de prestígio na sociedade colonial. Para tanto, fazia-se uso da legislação e dos mecanismos judiciais para resguardar o direito da educação aos órfãos de posse.

A instrução dos meninos tinha como propósitos dar continuidade às atividades econômicas e conduzir os assuntos da família. Por outro lado, a instrução das meninas esteve voltada para as atividades do lar, a criação dos filhos e a subserviência ao marido, pai e irmãos, chegando a serem enclausuradas em conventos ou internatos para receber uma educação exemplar, segundo os moldes daquela sociedade. Assim, o papel da mulher nesse contexto era de ser o exemplo de retidão, de passividade e de subserviência. 


\section{REFERÊNCIAS}

BOSI, Alfredo. Dialética da colonização. São Paulo: Companhia das Letras, 1992.

CASIMIRO, Ana Palmira Bittencourt Santos. Igreja, educação e escravidão no Brasil Colonial. Revista Politeia: História e Sociedade, Vitória da Conquista, BA, v. 7. n. 1, p. 85-102, 2007. Disponível em: <http:// periodicos.uesb.br/index.php/politeia/issue/view/22>. Acesso em: 16 set. 2016.

CHAMBOULEYRON, Rafael. Jesuítas e as crianças no Brasil quinhentista. In: DEL PRIORE, Mary del (Org.). História das crianças no Brasil. São Paulo: Contexto, 2004. p. 55-83.

FARIA, Sheila de Castro. A colônia em movimento: fortuna e família no cotidiano colonial. Rio de Janeiro: Nova Fronteira, 1998.

HOBSHAWM, Eric. Era dos extremos: o breve século XX (1914-1991). Tradução de Marcos Santarrita. São Paulo: Companhia das Letras, 1995.

MANACORDA, Mario Alighiero. História da educação. São Paulo: Cortez, 1989.

SANTOS, Vera Maria dos. A mulher de posses e a instrução elementar na Capitania de Sergipe Del Rey nos anos setecentos. 2011. Tese (Doutorado em Educação) - Universidade Federal de Sergipe (UFS), São Cristóvão, SE, 2011.

SAVIANI, Dermeval. História das ideias pedagógicas no Brasil. 3. ed. Campinas, SP: Autores Associados, 2011.

SAVIANI, Dermeval et al. O legado educacional do século XIX. 2. ed. rev. Campinas, SP: Autores Associados, 2006

\section{FONTES}

ORDENAÇÕES FILIPINAS. Portugal: Universidade de Coimbra, 1870. Disponível em: <http://www.uc.pt/ ihti/proj/filipinas/ordenacoes.htm> Acesso em: 29 out. 2016.

\section{Sobre os autores:}

Gleidson Silva: Mestrando em Educação na Universidade Tiradentes (UNIT). E-mail: gleidson.edu@live.com

Simone Silveira Amorim: Doutora em Educação. Professora no Programa de Pós-Graduação em Educação da UNIT. E-mail: amorim_simone@hotmail.com 